\section{Going the Extra Mile: Impact of Individuals' Behavior on Information Technology Governance}

\author{
Indo Além: Impacto do Comportamento dos Indivíduos na Governança da \\ Tecnologia da Informação
}

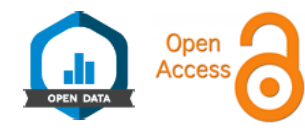

Guilherme Costa Wiedenhöft*1 $\odot$ Edimara Mezzomo Luciano ${ }^{2}$

\section{ABSTRACT}

Objective: this work emphasizes the information technology governance (ITG) behavioral expression and aims to identify whether individual behavior contributes to the increase of the perceived maturity of the ITG mechanisms. The organizational citizenship behavior (OCB) concept was the base to develop a model of relations between individual behavior and ITG maturity. Methods: we carried out a survey with 243 IT personnel of the executive branch of a Brazilian state government. We used partial least squares as data analysis technique. Results: the findings show the existence of a positive and significant relationship between the variable spirit of initiative and the perceived maturity of the ITG mechanisms. Conclusions: the impact of ITG changes in individuals' behavior needs to be considered, which reinforces that ITG is a critical resource for implementing public policies and executing governmental strategies. In order to raise the IT governance maturity, managers should foster the spirit of initiative in their teams, acting on their antecedents such as feelings of control, complexity, self-efficacy, and responsibility for changes. Consequently, individuals can make a deliberate decision, constantly evaluating the likely outcomes of their behaviors in favor of the adoption of ITG mechanisms.

Keywords: information technology governance; IT governance mechanisms; organizational citizenship behavior; public organizations; partial least squares.

\section{RESUMO}

Objetivo: este trabalho destaca a expressão comportamental da governança de tecnologia da informação (GTI) e visa a identificar se o comportamento dos indivíduos contribui para o aumento da percepçáo de maturidade dos mecanismos de GTI. O conceito de comportamento de cidadania organizacional (CCO) foi a base para desenvolver um modelo de relacionamento entre o comportamento dos indivíduos e a maturidade da GTI. Método: uma survey foi realizada com 243 profissionais de TI do poder executivo de um governo estadual brasileiro. Os mínimos quadrados parciais foram usados como técnica de análise de dados. Resultados: os achados mostram a existência de uma relaçáo positiva e significativa entre a variável espírito de iniciativa e a percepçáo de maturidade dos mecanismos de GTI. Conclusóes: o impacto das mudanças da GTI no comportamento dos indivíduos precisa ser considerado, o que reforça que GTI é um recurso crítico para a implementaçáo de políticas públicas e a execução de estratégias governamentais. Para elevar o nível de maturidade da governança de TI, os gestores devem fomentar o espírito de iniciativa em suas equipes, atuando sobre seus antecedentes como sentimentos de controle, complexidade, autoeficácia e responsabilidade pelas mudanças. Como consequência, os indivíduos podem tomar uma decisão deliberada, avaliando constantemente os resultados prováveis de seus comportamentos em favor da adoção de mecanismos de GTI.

Palavras-chave: governança da tecnologia da informação; mecanismos de governança de TI; comportamento da cidadania organizacional; organizaçóes públicas; mínimos quadrados parciais.

\footnotetext{
* Corresponding Author.

1. Universidade Federal do Rio Grande, Instituto de Ciências Econômicas, Administrativas e Contábeis, Rio Grande, RS, Brazil.

2. Pontifícia Universidade Católica do Rio Grande do Sul, Business School, Porto Alegre, RS, Brazil. Cite as: Wiedenhöft, G. C., \& Luciano, E. M. (2021). Going the extra mile: Impact of individuals' behavior on information technology governance. Revista de Administração Contemporânea, 25(5), el90237. https://doi.org/10.1590/1982-7849rac2021190237.en
}

\# of invited reviewers until the decision:

\begin{tabular}{|c|c|c|c|c|c|c|c|c|c|}
\hline & 1 & 2 & 3 & 4 & 5 & 6 & 7 & 8 & 9 \\
\hline $1^{\text {st }}$ round & $x$ & (x) & 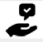 & (x) & (x) & (x) & $\stackrel{\varphi}{2}$ & (x) & \\
\hline $2^{\text {nd }}$ round & 电 & 8 & & & & & & & \\
\hline $3^{\text {rd }}$ round & ह & & & & & & & & \\
\hline
\end{tabular}

JEL Code: L15, D73, C91. Editor-in-chief: Wesley Mendes-da-Silva (Fundação Getulio Vargas, EAESP, Brazil) (1) Reviewers: Fernando Zaidan (Instituto de Educação Tecnológica - IETEC, Brazil) (C) Henrique Pontes G. de Oliveira (Fundação Getulio Vargas, EAESP, Brazill) Peer Review Report: The Peer Review Report is available at this external URL. Accepted: August 26, 2020 


\section{INTRODUCTION}

Connections between government and citizens are changing, and this process generates new demands for data, information, and fast and reliable services whose operationalization depends, involves, or is made possible by information technology (IT) solutions (Wiedenhöft, Luciano, \& Pereira, 2019). A formalized and structured process of governance is necessary to avoid the uncontrolled development of solutions and to reduce the amount of ad hoc solutions (Nfuka \& Rusu, 2011), as well as the conflict generated by the divergent interests among stakeholders (Collares, 2020). Without governing IT, redundant solutions are likely to happen, leading to an unnecessary rise of complexity, increasing the transaction costs and compromising future investments in new initiatives.

Governance in public organizations involves processes and structures for decision-making on public policies and their management, as a way to engage actors from different government levels and other public and private agents to achieve a public purpose that could, otherwise, not be attained (Peters, 1998). Information technology governance (ITG) is a set of arrangements and patterns of authority and strategic IT activities (Sambamurthy \& Zmud, 1999). It is composed of structure, process, and relationship mechanisms (Weill \& Ross, 2004), which constitute the practical operationalization of ITG definitions such as principles and high-level objectives. ITG also involves decision-making structures and IT decision rights and responsibilities to encourage the desired behavior (Weill \& Ross, 2004).

Considering that IT has political and social implications (Bekkers \& Homburg, 2002), ITG adoption changes the meaning of IT in organizations, since central IT issues are becoming gradually not related to technical issues, but to the policies associated with how technology should be used to generate public value. In the public sector, these changes in the understanding of IT implementation become a tool to increase trust and promote a participatory citizengovernment relationship as well as a means for equitable IT policies (Schwarz, 2005).

Studies on ITG suggest two main pillars of action to enhance the maturity level of ITG mechanisms in organizations: one that focuses on legal and regulatory aspects, and another that focuses on behavioral aspects inherent to individuals dealing with IT. ITG mechanisms should encourage the desired behavior of individuals related to IT (Weill \& Ross, 2004), contributing to a consistent and aligned relationship between business and IT. This behavioral expression of ITG is the focus of this research.

In public organizations, normative and control mechanisms are not sufficient to achieve ITG effectiveness since the presence of discretionary power gives civil servants the possibility to interpret normative controls and decide not to fully follow them, corroborating the importance of individuals' behavioral change. Moreover, there are several unclear situations caused by overlapped, dubious, or inexistent procedures. Individuals must interpret these situations and make decisions to better contribute to meet citizen demands and to reach government goals. Non-described behaviors (in laws, decrees, and policies) are necessary to solve conflicts created by non-regulated situations, i.e., the conflicts between the job description and the necessary extra-role behavior to guarantee the achievement of the organizational goals.

The IT governance model conception occurs under an institutionalization process (Currie, 2008). Therefore, the ITG mechanisms' adoption level can be influenced by a cognitive institutionalization process resultant from a regulatory, normative, or mimetic pressure related to the perceived importance of the ITG mechanisms (Scott, 1995). Consequently, the IT governance mechanisms maturity (ITGMM) can vary depending on the individual behavior, and it is measured by the mechanisms' adoption level and its contribution to reaching the goals while principles are respected (Currie, 2008; Wiedenhöft, Luciano, \& Porto, 2019). ITG principles work also as a promoter of strategic alignment (Luna-Reyes, Juiz, Gutierrez-Martinez, Duhamel, 2020).

Organizational citizenship behavior (OCB) was the selected concept to understand the extra-role behavior related to ITG adoption. OCB describes a person's voluntary commitment to an organization and the attitudes that are not part of his or her contractual functions (Cunha, Rego, \& Clegg, 2010). It is characterized by the existence of employee protection actions, aiming to safeguard organizations and everything that belongs to them, contributing to a favorable environment. The research question is: Which are the effects of individual behavior in the adoption of ITG mechanisms? The goal of this study is to identify which dimensions of organizational citizenship behavior contribute to the increase of the perceived maturity of IT governance mechanisms in public organizations.

In addition to this Introduction, the article has four more sections. We present the theoretical framework that supports the research in the theoretical background section. The third section presents the methodological procedures adopted, followed by the results and main findings (in Research method section). The fifth section discusses the final remarks and suggestions for future researches.

\section{THEORETICAL BACKGROUND}

This section presents the theoretical foundations of this study. 


\section{IT Governance behavioral approach - related work}

Even though the literature on IT governance has been increasing and becoming more comprehensive, the behavioral approach is not frequent. There are just a few studies that involve both concepts simultaneously, even though Weill and Ross mentioned the presence of a behavioral side to IT governance many years ago (Weill \& Ross, 2004). We only found 15 papers on Scopus and Web of Science databases when searching for IT governance and behavior (or behaviour) on title, abstract, and keywords. These papers were published from 2008 to 2020 .

Currie's work presents the findings of a longitudinal qualitative research study on an IT-based investment management system. The authors use institutional theory to identify that the institutionalization process follows a nonlinear pathway where regulative, normative, and cultural forces within the investment management industry produce conflicting organizational behaviors and outcomes (Currie, 2008). The paper presents an approach similar to this research, although it focuses on IT and not on IT governance.

The study of Zerpa analyzed the main characteristics of the e-government maturity model developed by the e-Government and Information and Knowledge Society Agency (AGESIC) of Uruguay and described examples of desirable behaviors necessary to reach e-government maturity (Zerpa, 2009). The paper approaches behavioral aspects of public organizations, as this research, even though it is not focused on IT governance. Similarly, the study of He, Ye, and $\mathrm{Xu}$ (2010) analyzed the influence of human factors on hierarchy in a changing context. Results showed that organizations need to implement IT governance effectively to guide the organizational changes as a way to enhance hierarchical structures and avoid the effects of lacking supervision and the agency problem.

Bradley and Pratt (2011) studied how entrepreneurial behavior influences the focus on IT governance and IT risk management, showing that corporate entrepreneurship acts as an antecedent to both IT governance and IT risk management. The paper establishes a causal relationship between IT governance and IT risk management and introduces culture strength as a moderator of the relationship between corporate entrepreneurship and IT risk management.

The IT practitioners' influence on the extent of their participation in ITG initiatives was studied by Teo, Manaf, and Choong (2013). Using the theory of planned behavior, the authors carried out a quantitative study among IT practitioners. They suggest that awareness and perceived importance of ITG are the two most important factors from the practitioner perspective. The authors reaffirm that ITG requires control in the form of organizational structures, processes, goal settings, and reward systems to encourage desirable behaviors in IT governance initiatives. Magnusson and Bygstad (2013) also studied practitioners, focusing on understanding how $\mathrm{CIO}$ relate to the norm system by studying how they legitimate ITG practices. The study illustrates that $\mathrm{CIOs}$ tend not contesting IT governance-related norms unless these conflict with neighboring professional jurisdictions.

An ITG maturity model was the focus of the study of Smits and Van Hillegersberg, which focuses on the hard and soft sides of IT governance (Smits \& Van Hillegersberg, 2015, 2014). Their study reveals an ITG maturity model as being appropriate for hard ITG. For soft ITG, no single model was found appropriate, which demands more specific capabilities defined for each area individually, due to the impact of elements like a trusted environment and organizational culture. Lin and Wittmer (2017) demonstrate the positive relationship of individual creativity and group culture, as well as mediation effects of decentralized ITG and individual creativity on the relationship between proactive information security behavior and group culture. The research of Morisse et al. (2014) presents that ITG can impact trust while a trustworthy environment contributes to ITG adoption.

Other three papers, after a set of studies in the Brazilian government subnational level, claim that ITG institutionalization exerts a positive effect on behavior since the ITG legitimation process enhances the perception of organizational justice through transparency and equity increase (Wiedenhöft, Luciano, \& Macadar, 2016; Wiedenhöft, Luciano, \& Pereira, 2019; Wiedenhöft, Luciano, \& Porto, 2019). A more recent research showed that when OCB levels are higher, ITG is more easily perceived as effective (Wiedenhöft, Luciano, \& Pereira, 2019). The authors claim that a reason for it is the probability that the predisposition to adopt ITG mechanisms increases the governance process' changes, which the organization understood as significant.

Even considering the contribution of the mentioned publications, the subject remains understudied and the relationship between ITG and OCB still offers a great opportunity for further studies.

\section{IT governance in public organizations}

The emergence of e-government and electronic services to citizens pressured for changes in the public management model (Diniz, Barbosa, Junqueira, \& Prado, 2009). Likewise, IT has highly contributed to the growing demands for governmental transparency and accountability (Joia \& Magalhães, 2009). Recent technological changes have been improving the collaboration and cooperation among public sector organizations and have a vital role in delivering transparency and accountability (Ali, Nor, Abdullah, \& Murad, 2016). The internet has brought greater 
visibility to public organizations, spreading e-government applications worldwide, which increased the number of public organizations that use ICT (Dada, 2006).

ITG in public organizations has a significant influence on the political environment and the value system, which emphasizes compliance with legal provisions (Joia \& Magalhães, 2009). Public and private sector's IT governance models are similar in their fundamental pillars (principles, objectives, and mechanisms). However, the sectors are very different in the environmental aspects that involve the characteristics of external and internal institutional pressures. Institutional pressures represent an important source of IT demands in public organizations, whereas the financial and market pressures inherent to the private sector drive the demands on private organizations. The most considerable divergence between the public and the private sector lies in how the agents responsible for governance react to these pressures (Rodrigues \& Souza Neto, 2012).

ITG in public organizations involves the capacity to implement public policies that aim at robust state capacity by creating a strategic nucleus to make the necessary decisions and providing a qualified and motivated bureaucracy. Internal aspects of public administration, such as processes, relationships, and structures, are also part of the ITG discussion in public organizations, as well as external aspects such as public services, participation, and control (Mendonça, Guerra, Souza Neto, \& Araújo, 2013).

The main difference between ITG in the private and public sector lies in the fact that the public sector provides public goods and services instead of selling products or services. The complex IT environment and the weaknesses of the ITG in the Brazilian public sector are mainly caused by the absence of good public governance (Mendonça et al., 2013) and by the insufficient consideration of institutional and behavioral aspects.

\section{Organizational citizenship behavior}

Organizations can be understood as an activity system where two or more people integrate efforts in a conscious and coordinated manner (Barnard, 1938). People aggregate themselves to an organization due to the human ability to share a purpose, the willingness related to organizational processes, and the ability to communicate (Cruz, 2004). There are some fundamental behaviors for organizational dynamics, such as to enter and to remain in a system, and to show reliable, innovative, and spontaneous behavior (Katz $\&$ Kahn, 1978). According to the authors, innovative and spontaneous behavior is essential to the organization because it leads to a higher performance necessary for the achievement of organizational goals. These three factors are the core of the organizational citizenship behavior construct (Siqueira, 2003).

Organizations' members are not always intrinsically cooperative and inter-related, just like they are in their private lives. Organizational citizenship behavior is characterized by the existence of system protective actions, aiming to safeguard the organization and whatever belongs to it (Smith, Organ, \& Near, 1983). It is also characterized by the efforts of members to take responsibility for their education, aiming to improve the performance in their activities and to prepare them to take more responsibilities in the organization. Members are frequently presenting new ideas to the managers and cooperating to develop a favorable environment to face external organizational challenges.

The importance of OCB to organizations is related to their need for flexibility to face many of the unmapped situations that arise in everyday life (Smith et al., 1983). The dimensions of organizational citizenship behaviors have, at the same time, behaviors related to the attitudes of the individual concerning the organization and to other individuals (Rego \& Cunha, 2010). Organizational citizenship relationships occur when individuals adopt a posture that benefits the organization's image. Based on the premise that OCB has a contingency characteristic, Rego sought to operationalize and validate a measurement instrument adapted to the Portuguese reality, in which four OCB dimensions emerged (Rego, 1999). These dimensions are described in Table 1.

Table 1. OCB dimensions in the Portuguese-Brazilian context.

\begin{tabular}{ll}
\hline \multicolumn{1}{c}{ OCB dimension } & Description \\
\hline Conscientiousness $(\mathrm{CO})$ & $\begin{array}{l}\text { Revects behaviors of conformity, conscientiousness, and protection of organizations' resources } \\
\text { make constructive suggestions for improvement }\end{array}$ \\
Spirit of initiative (SI) & $\begin{array}{l}\text { Is related to interpersonal harmony, participation, team spirit, camaraderie, and sharing of knowledge and } \\
\text { experience }\end{array}$ \\
Interpersonal harmony (IH) & $\begin{array}{l}\text { Denotes that the individual makes extra efforts and seeks to defend the image of the organization with } \\
\text { attitudes that exalt its positive aspects toward people outside the organization }\end{array}$ \\
Identification with the organization $(\mathrm{IO})$
\end{tabular}

Note. Source: Rego (1999). 
Organizational citizenship behavior was chosen because its meaning is aligned with the desirable behavior encouraged by corporate governance and, consequently, by IT governance (Bies, 1989; Organ, 2015). This behavior is associated with a set of informal contributions that an organization's participants can manifest or inhibit without answering formal objections or sanctions (Siqueira, 2003).

\section{THEORETICAL-EMPIRICAL MODEL}

In this section, we develop the theoretical model of the study and formulate the hypotheses.

Human behavior is the result of a series of cognitive and affective events, which is often preceded by the conscious intention of acting. Several theories focus on analyzing the relations between human behavior and organizational aspects. The theory of reasoned action (TRA), originated from social psychology, tries to identify the determinants of the intended conscious behavior (Ajzen \& Fishbein, 1977; Bentler \& Speckart, 1979). TRA considers that the primary behavior antecedent is the individual's intention to behave, which is determined by the attitude towards a target behavior, subjective norms, and affective and cognitive issues. In addition to TRA, Ajzen proposed the theory of planned behavior (TPB), adding one more construct related to the intention to use or intention to do (Ajzen, 1991).

TPB is a theory conceived to predict and explain human behavior in specific contexts, for example, in adopting new technologies, tools, or processes (Ajzen, 1991). According to the authors, the stronger the employees' intention to engage in some specific behavior, the more likely is their performance in that behavior. Considering that, the process of ITG institutionalization can be influenced by the behavior of individuals and consequently influence the level of ITGMM in organizations.

The individuals behavior is an essential variable because the adoption of management models often fails due to inadequate human behavior, and good behavior compensates the deficiencies in the management model (Collares, 2020). ITG mechanisms express IT-related corporate governance aspirations (De Haes \& Van Grembergen, 2009; Weill \& Ross, 2004). The individuals' behavior can influence this structure, and the performance of the organization depends on the employees' intention to perform actions not foreseen in the formal work contracts.

The OCB concept is related to behaviors that are not specifically part of the individuals' roles but are very important to the organization. Desirable behavior is a way to go beyond the complacent behavior generally linked to the ITG practices adoption, since it is essential for long-term IT planning and for the ITG adoption effectiveness. Based on these theoretical foundations, the general hypothesis of this study is that the OCB dimensions contribute to increasing the ITG mechanisms perceived maturity in public organizations. Thus, the theoretical-empirical model shown in Figure 1 was created by combining the variables related to IT governance mechanisms maturity based on Wiedenhöft, Luciano, and Magnagnagno (2017) and the OCB model validated by Rego $(1999,2003)$.

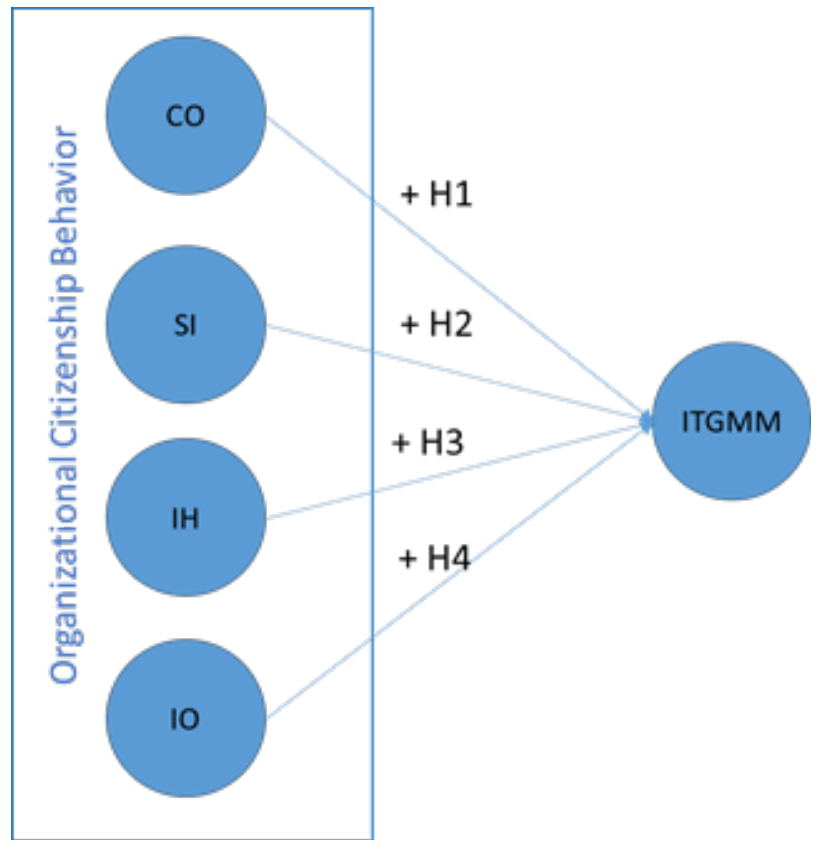

Figure 1. Theoretical-empirical model.

Source: elaborated by the authors.

The theoretical-empirical model demonstrates that the maturity of the IT governance mechanisms is positively influenced by the organizational citizenship behavior construct variables. Considering that, the methodological procedures performed should test the specific hypotheses discussed below.

ITG institutionalization model exerts a positive effect on the consciousness behavior since the relationship mechanisms can make employees aware of the importance of the correct use and preservation of IT resources (Wiedenhöft, Luciano, \& Pereira, 2019). Consequently, individuals can more spontaneously contribute to the increase of ITG maturity, since ITG control and feedback mechanisms lead them to be more disciplined and sensitive to organizational issues (Teo, Manaf, \& Choong, 2013). Based on that, we established the following hypothesis:

Hypothesis 1: The consciousness behavior positively influences the perception of IT governance mechanisms maturity. 
ITG model institutionalization can change the individuals' perception of how intrinsically satisfactory their tasks are, since ITG mechanisms are seen as promoting fairer environments, as clear definitions of responsibilities reduce the ambiguity and the conflict of individuals in understanding their roles in the organization (Wiedenhöft, Luciano, \& Pereira, 2019). When the organizational practices converge to role clarity, the organizational fairness increases, leading individuals to proactivity solve problems and to find alternative solution to them, and to spontaneously suggest improvements to the organization (Rego \& Cunha, 2010). Consequently, ITG institutionalization favors the spirit of initiative, increasing individuals' efforts to improve ITG maturity. Based on that, we established the following hypothesis:

Hypothesis 2: The spirit of initiative behavior positively influences the perception of IT governance mechanisms maturity.

ITG model institutionalization can exert a positive impact on the interpersonal harmony, since the more institutionalized the governance model, the higher the individuals' willingness to solve issues and to find alternative solutions to them (Wiedenhöft, Luciano, \& Pereira, 2019). Consequently, interpersonal harmony behavior contributes to shared understating of conjoint business and IT necessities, reducing conflicts on teams and favoring IT mechanisms adoption and maturity. Based on that, we established the following hypothesis:

Hypothesis 3: The interpersonal harmony behavior positively influences the perception of IT governance mechanisms maturity.
ITG institutionalization model augments the perception of organizational support through equity and transparency mechanisms (Wiedenhöft, Luciano, \& Pereira, 2019). Organizational support amplifies the belief in organizational reciprocity (Ahmed \& Nawaz, 2015), which stimulates the adoption of pro-organization behaviors (Fernandes, Siqueira, \& Vieira, 2014). Therefore, the identification with the organization behavior stirs the individual behavior in favor of the organization and its mechanisms. Based on that, we established the following hypothesis:

Hypothesis 4: The identification with the organization behavior positively influences the perception of IT governance mechanisms maturity.

The following section presents the details of the methodological procedures used to evaluate the hypotheses mentioned above.

\section{RESEARCH METHOD}

This exploratory and descriptive cross-sectional research presents a quantitative approach due to the data collection and analysis techniques used. We performed a survey because it was the most appropriate approach to reach the research goals. We carried out data collection in the executive branch direct administration of the Government of Rio Grande do Sul (RS) State, Brazil, which has around 1,200 employees in the IT area. Figure 2 shows the main methodological steps.

\section{Data collection}

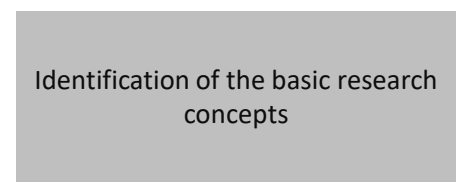

Literature review

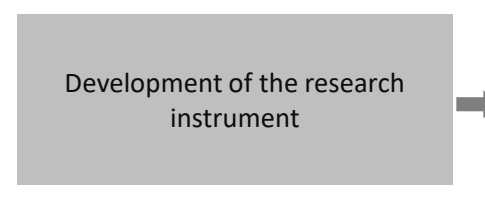

(Rego \& Cunha, 2010)

(Luciano et al., 2016)

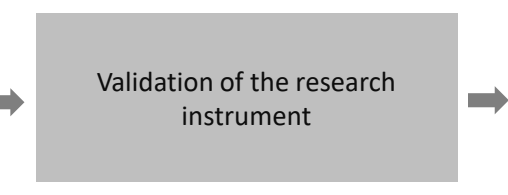

Application of Interviews and Factor Analysis (Hair et al., 2014)
Application of research data collect instrument

A survey with IT teams of public organizations in a Brazilian

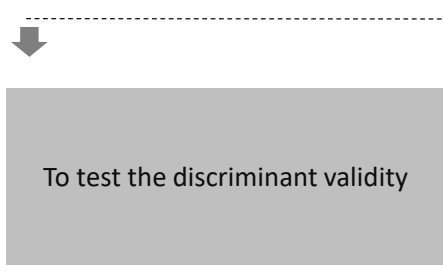

PLS Algorithm: Cross Loading (Chin, 1998; Hair et al., 2014) Fornell and Larcker (1981) criteria

\section{Data analysis}

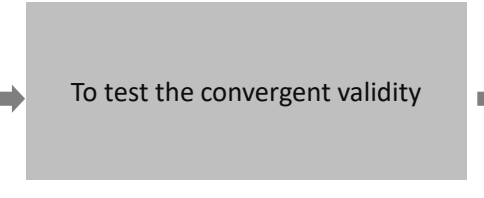

PLS Algorithm: Average Variance Extracted (Henseler, Rigle, \& Sinkosvics, 2009); Outer Loadings (Hair et al., 2014)

\section{To test the the reliability}

PLS Algorithm: Composite reliability - CR e Cronbach's Alpha (Hair et al., 2014)
To evaluate the significance of correlations in order to test the relationships between OCB/ITGMM

Bootstrapping: $t$ Test $>1.96$

(Ringle, Silva, \& Bido, 2014)

Figure 2. Research steps.

Source: elaborated by the authors. 


\section{Questionnaire development and validation}

We developed a questionnaire to verify the relations between ITG and individuals' behavior, comprising of three parts, namely: (a) evaluation of the ITG mechanisms perceived maturity through 11 questions based on Wiedenhöft, Luciano, and Pereira (2017); (b) 15 questions from the OCB model validated by Rego (1999, 2003); and (c) 11 socio-demographic questions. Four experts in the field analyzed and contributed with suggestions to the first version of the questionnaire. The 11 members of the ITG Steering Committee in the RS State performed the face and content validation, and their suggestions were considered for the new version of the instrument. Some questions were rephrased, aiming at a better understanding, and the question related to the mechanism E05 (CIO at the executive level and the board of directors) was removed since it did not apply to the context of public administration.

We pre-tested the instrument through a survey with IT civil servants of the RS State government. We used the free software $G^{*}$ Power 3.1.9 to test the sample post hoc. The sample power test for the 74 valid cases resulted in a $1-\beta$-error probability equal to 0.7336 , with 0.15 effect size (f2). Literature recommends power values close to 0.80 and an effect size of 0.15 (Sarstedt, Ringle, Smith, Reams, \& Hair, 2014). The pre-test sample was considered adequate despite the small difference between the recommended and achieved values.

The result of the Kaiser-Meyer-Olkin (KMO) test in the correlation matrix was 0.781 , showing that there was data adequacy to perform the factorial analysis. The Bartlett sphericity test $\left(X^{2}=1,797.802 ; \mathrm{df}=465 ; \mathrm{p}=0.000\right)$ showed that the variables are correlated, according to $\mathrm{p}$-value analysis $(\mathrm{Sig}=0.000)$, which is less than 0.05 .

The results presented by these tests showed that the five factors corresponded to $71.54 \%$ of the total variance explained. We performed the Cronbach's alpha test $(0.862)$ to test the reliability of the research instrument, and the standardized items $(0.850)$ denoted the applicability of the instrument for data collection.

\section{Data collection}

Printed questionnaires were distributed, and 264 were filled out. We applied the data purification procedures suggested by Sarstedt, Ringle, Smith, Reams and Hair (2014), leaving 243 valid answers. The valid answers for the final analysis represent a heterogeneous sample of the RS State direct administration. We carried out a random sample separation procedure to guarantee the absence of respondent bias, and divided the sample into two groups (A and B). Then, we compared the means to see if there would be a significant difference between the samples. The result $(4.42 ; 4.56)$ showed that the difference is not significant $(t=0.95,1-p=65.6 \%)$, attesting the absence of respondents' bias.

We chose the estimation of structural equations by partial least squares (SEM-PLS) because the Kolmogorov-Smirnov test showed that it is not possible to determine the normality of data and in PLS technique there is no such assumption of normality for the use of the technique (Sarstedt et al., 2014). We performed the analysis through SmartPLS ${ }^{\oplus}$, version 2.

\section{Data analysis}

For the analysis of the structural model, the first observed indicator was the Pearson determination coefficients $\left(\mathrm{R}^{2}\right)$ (Sarstedt et al., 2014). The $\mathrm{R}^{2}$ indicators evaluate the portion of the variance of the endogenous variables that are explained by the structural model. These indicators show the quality of the adjusted model. The convergent validities are obtained by average of variances extracted (AVEs). The second indicator is the Fornell and Larcker criterion (Sarstedt et al., 2014), in which AVE values should be higher than 0.50 (AVE > 0.50) (Sarstedt et al., 2014). When this is true, it is understood that the model converges to a satisfactory result (Fornell \& Larcker, 1981).

We performed the analysis of the internal consistency of the model through composite reliability (CC). The traditional indicator is Cronbach's alpha (CA), which is based on the intercorrelations of the variables. However, the $\mathrm{CC}$ indicator is more suitable to PLS-PM because it prioritizes the variables according to their reliability, while the $\mathrm{AC}$ is very sensitive to the number of variables in each construct. Furthermore, both CA and CC should be used to assess whether the sample is free of bias, or whether the responses (as a whole) are reliable.

Finally, to evaluate the significance of the results obtained from the SmartPLS ${ }^{\oplus}$, the bootstrapping module calculates Student $\mathrm{t}$-tests between the original data values and those obtained by the resampling technique for each correlation between the latent and observed variables. The result of bootstrapping on SmartPLS shows the t-test values instead of p-values. Thus, we calculated the p-values considering the results of the $\mathrm{t}$-tests and the degrees of freedom values.

\section{RESULTS ANALYSIS}

We inserted collected data into SmartPLS ${ }^{\varpi}$ in order to test the proposed model. Next, we elaborated the first-order model, in which each of the four OCB construct variables was linked to the ITGMM construct. The result can be observed in Figure 3, where the following variables can be found: spirit of initiative (SI), consciousness (CO), identification with the organization (IO), interpersonal harmony (IH), and IT governance mechanisms maturity (ITGMM). 


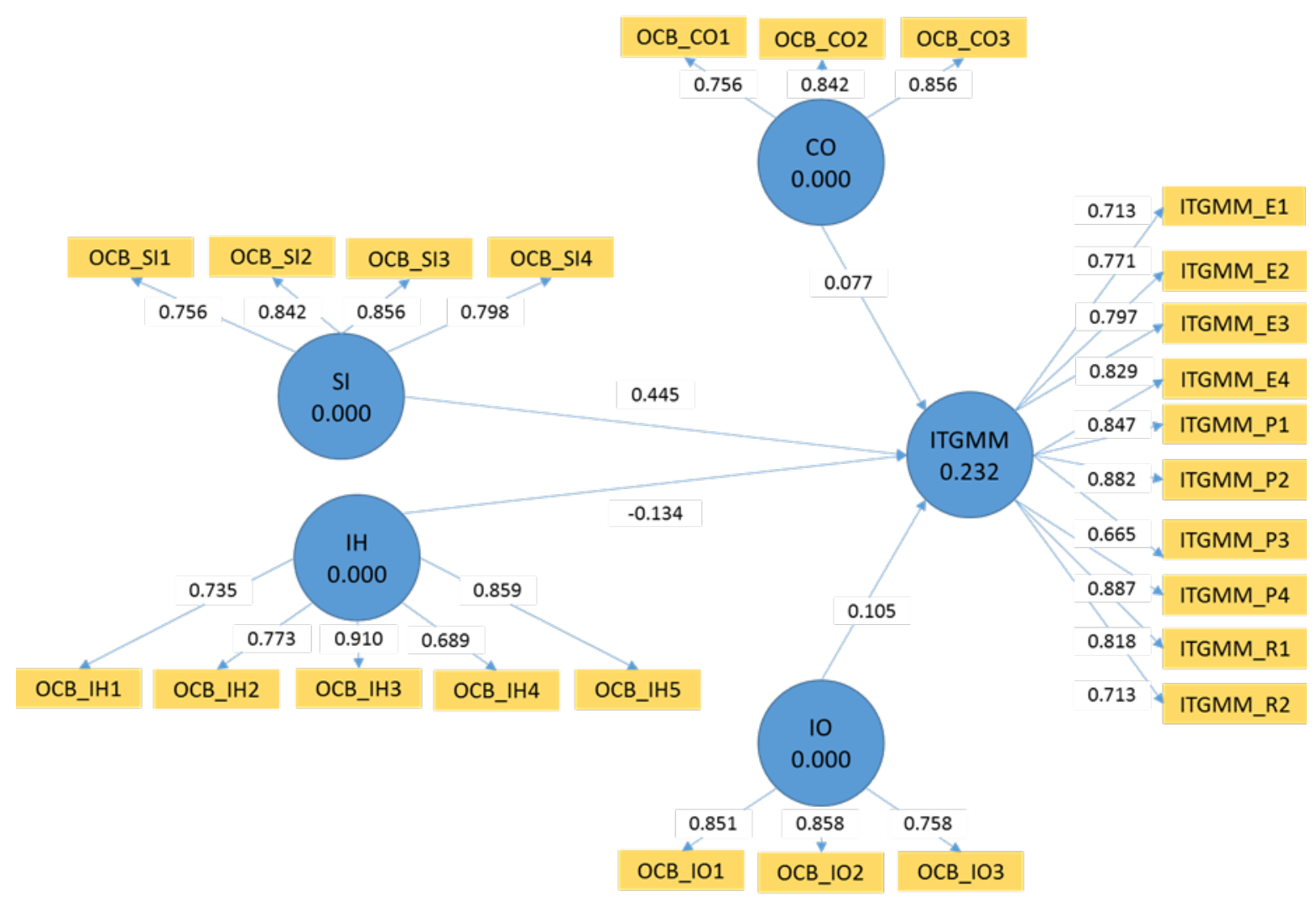

Figure 3. Relationship between OCB dimensions and the ITG mechanism perceived maturity.

The figure presents the measurement model with the values of the correlations between observed and latent variables. Inside the ITGMM circles, the $\mathrm{R}^{2}$ value of the dependent variable is displayed. The arrows between the circles show the linear regression path coefficient presenting the causal relationship between the independent and dependent latent variables. Source: elaborated by the authors.

The analysis of the measurement model started with the assessment of the discriminant validity, which was obtained since the latent constructs or variables are not interdependent (Sarstedt et al., 2014). Table 2 presents the discriminant validity test based on cross loading analysis (Chin, 1998).

We present the results obtained in the convergent validity and reliability test in Tables 3 and 4 .

The Table 4 presents the convergent validity according to Fornell and Larcker criterion (Henseler, Ringle, \& Sinkovics, 2009).

The first value in the analysis of the structural model is related to Pearson determination coefficients $\left(R^{2}\right)$. In Social and Behavioral Sciences, $\mathrm{R}^{2}>0.02$ is classified as a small effect, $\mathrm{R}^{2}>0.13$ as a medium effect, and $\mathrm{R}^{2}>0.26$ as a large effect (Sarstedt et al., 2014). These coefficients evaluate the portion of the variance of the endogenous variables that is explained by the structural model, indicating the quality of the adjusted model (Sarstedt et al., 2014) (Table 5).

All the performed tests show the suitability of the proposed model, allowing the hypothesis test to be carried out. Table 5 shows the sizes of the effects and significance of the relationships identified between the OCB variables and the ITGMM variable (Ringle, Silva, \& Bido, 2014) (Table 6).

Even though the behavioral dimensions conscientiousness, interpersonal harmony, and identification with the organization are not significantly related to the ITG mechanisms maturity, spirit of initiative positively influences the maturity of the adopted ITG mechanisms. Spirit of initiative can contribute to the effectiveness of ITG mechanisms, as it can increase the intention of the use of mechanisms by other employees and increase their proactivity in fixing the ITG model deficiencies. 
Table 2. Cross loading analysis.

\begin{tabular}{|c|c|c|c|c|c|}
\hline Variables & $\mathrm{CO}$ & SI & $\mathrm{IH}$ & $\mathrm{IO}$ & ITGMM \\
\hline OCB_CO1 & 0.9239 & -0.4434 & 0.7134 & -0.1735 & -0.2463 \\
\hline OCB_CO2 & 0.7628 & -0.3784 & 0.5620 & -0.1374 & -0.1103 \\
\hline OCB_CO3 & 0.8251 & -0.4262 & 0.7291 & -0.2110 & -0.1135 \\
\hline OCB_SI1 & -0.3475 & 0.7563 & -0.3810 & 0.3091 & 0.3911 \\
\hline OCB_SI2 & -0.4117 & 0.8422 & -0.4188 & 0.3254 & 0.3638 \\
\hline OCB_SI3 & -0.4107 & 0.8563 & -0.4526 & 0.3901 & 0.3821 \\
\hline OCB_SI4 & -0.4310 & 0.7977 & -0.4141 & 0.5181 & 0.3723 \\
\hline OCB_IH1 & 0.6064 & -0.3777 & 0.7353 & -0.1477 & -0.0642 \\
\hline OCB_IH2 & 0.6703 & -0.3630 & 0.7734 & -0.0351 & -0.0490 \\
\hline OCB_IH3 & 0.6988 & -0.4987 & 0.9099 & -0.2408 & -0.2143 \\
\hline OCB_IH4 & 0.6981 & -0.4474 & 0.8886 & -0.1920 & -0.1407 \\
\hline OCB_IH5 & 0.6823 & -0.4109 & 0.8586 & -0.1148 & -0.1457 \\
\hline OCB_IO1 & -0.1550 & 0.4036 & -0.1971 & 0.8613 & 0.2745 \\
\hline OCB_IO2 & -0.1662 & 0.4406 & -0.1558 & 0.8676 & 0.2533 \\
\hline OCB_IO3 & -0.1852 & 0.3323 & -0.1441 & 0.7576 & 0.2300 \\
\hline ITGMM_E1 & -0.1948 & 0.3747 & -0.1532 & 0.1920 & 0.7126 \\
\hline ITGMM_E2 & -0.1550 & 0.2990 & -0.0862 & 0.1691 & 0.7212 \\
\hline ITGMM_E3 & -0.1437 & 0.3326 & -0.1183 & 0.2861 & 0.7967 \\
\hline ITGMM_E4 & -0.2189 & 0.3692 & -0.1713 & 0.2093 & 0.8289 \\
\hline ITGMM_P1 & -0.1765 & 0.3650 & -0.1196 & 0.2090 & 0.8473 \\
\hline ITGMM_P2 & -0.1599 & 0.3781 & -0.1447 & 0.2612 & 0.8816 \\
\hline ITGMM_P3 & -0.0936 & 0.3788 & -0.1278 & 0.2036 & 0.6663 \\
\hline ITGMM_P4 & -0.2068 & 0.3804 & -0.1868 & 0.2827 & 0.8673 \\
\hline ITGMM_R1 & -0.2065 & 0.3839 & -0.1498 & 0.2805 & 0.8184 \\
\hline ITGMM_R2 & -0.1057 & 0.3822 & -0.1189 & 0.2909 & 0.7181 \\
\hline
\end{tabular}

Note. The table presents the loading values between the observed variables and the constructs and should have higher values between the constructs and their observed variables. Source: elaborated by the authors.

Table 3. Convergent validity and reliability test.

\begin{tabular}{lcccc}
\hline \multicolumn{1}{c}{ Construct } & AVE & CR & AC & Communality \\
\hline OCB_CO & 0.7054 & 0.8771 & 0.8100 & 0.7054 \\
OCB_SI & 0.6627 & 0.8869 & 0.8292 & 0.6627 \\
OCB_IH & 0.6987 & 0.9201 & 0.8997 & 0.6987 \\
OCB_IO & 0.6895 & 0.8691 & 0.7732 & 0.6895 \\
ITGMM & 0.6226 & 0.9424 & 0.9312 & 0.6226 \\
\multicolumn{1}{r}{ Reference model } & AVE > 0.50 & CR $>0.70$ & AC > 0.70 & COM > 0.5 \\
\hline
\end{tabular}

Note. The table presents the results for average variance extracted (AVE), composite reliability (CR), Cronbach's alpha, and communalities, obtained in the convergent validity and reliability test. Source: elaborated by the authors. 
Table 4. Convergent validity - Fornell and Larcker criterion.

\begin{tabular}{ccccc}
\hline Construct & OCB_CO & OCB_SI & OCB_IH & OCB_IO \\
\hline OCB_CO & 0.840 & & & \\
OCB_SI & -0.492 & 0.814 & & \\
OCB_IH & 0.791 & -0.513 & 0.836 & 0.830 \\
OCB_IO & -0.202 & 0.474 & -0.201 & 0.305 \\
ITGMM & -0.212 & 0.465 & -0.176 & 0.789 \\
\hline
\end{tabular}

Note. The table presents the relationship between the construct's square root of average variance extracted (number in the top of columns) and correlation involving the constructs. Thus, the levels of the square root of the AVE for each construct should be higher than the correlation involving the constructs. Source: elaborated by the authors.

Table 5. Pearson determinant coefficients $\left(\mathrm{R}^{2}\right)$.

\begin{tabular}{lc}
\hline Variable & $R^{2}$ \\
\hline Conscientiousness (CO) & 0.077 \\
Spirit of initiative (SI) & 0.446 \\
Interpersonal harmony (IH) & -0.034 \\
Identification with the organization (IO) & 0.105 \\
\hline
\end{tabular}

Note. Source: elaborated by the authors.

Table 6. Constructs relation significance test.

\begin{tabular}{lrrrrrr}
\hline & $\begin{array}{c}\text { Original sample } \\
(\mathrm{O})\end{array}$ & Sample mean $(\mathrm{M})$ & Standard deviation & Standard error & T-statistics \\
\hline CO -> ITGMM & 0.077 & 0.068 & 0.090 & 0.090 & 0.857 & 0.3923 \\
SI $>$ ITGMM & 0.446 & 0.439 & 0.081 & 0.081 & 5.485 \\
IH -> ITGMM & -0.134 & -0.106 & 0.095 & 0.095 & 1.409 & $0.0001^{*}$ \\
IO -> ITGMM & 0.105 & 0.111 & 0.071 & 0.071 & 0.1600 \\
\hline
\end{tabular}

Note. ${ }^{*} \mathrm{p}$-value higher $(\mathrm{p}<0,001)$. Source: elaborated by the authors.

\section{DISCUSSION}

The adoption of ITG mechanisms is complex, since each mechanism implies significant changes in organizational structures, processes, and relationships among the decision-making roles. Furthermore, there is an impact on the constitutive actors since structural changes impact ITG processes and relationships. Thus, there are multiple and recurrent impacts, demanding civil servant's proactive conduct (which is the result of the spirit of initiative behavior) to increase the allegiance of ITG mechanisms to the organizational goals.

Initiatives exclusively based on ITG controls and regulatory compliance do not fully represent the ITG scope, as it also involves the incentive to desirable behavior in the use of IT, since it is not possible to establish policies, controls, and rules for all situations related to ITG adoption in organizations.
The spirit of initiative can contribute to civil servants' learning, training, motivation, and self-satisfaction, collaborating to reduce the resistance in the adoption of the ITG mechanisms. It is also understood that the civil servants' voluntary readiness to solve problems and find alternative solutions for the implementation of ITG mechanisms, besides spontaneity to make constructive suggestions for improvements, is a relevant factor for the maturity of ITG mechanisms.

Organizational citizenship behavior enables employees to be able to make their judgment about what is appropriate or not - the commitment to the organization acts as evidence that they will make the appropriate decision. In practical terms, this judgment involves identifying rules that do not make sense (e.g., looping procedures) or necessary actions not previously prescribed, but that are necessary to avoid the stagnation of activities. In countries with high levels of state bureaucracy, the laws, rules, and procedures are complex, numerous, and sometimes disconnected or 
overlapped, increasing the occurrence of over- or underregulated situations.

In both situations, OCB is fundamental for decisionmaking in situations with divergent, nonexistent, or insufficiently clear rules, aiming at the continuity of service delivery to society. This also contributes to the civil servants' sense of accomplishment, self-efficacy, and self-confidence (Bandura, 1989). The civil servants' spirit of initiative influences the faster and more effective adoption of ITG mechanisms, thus contributing to their maturity. In an organization that has a more mature ITG, IT contributes more effectively to the quality of e-services to citizens and, consequently, to the generation of public value.

This study suggests that public administration managers who wish to raise the maturity of IT governance mechanisms should create environments that favor the spirit of initiative behavior on their teams, acting on their antecedents such as feelings of control, complexity, selfefficacy, and responsibility for change (Parker, Williams, \& Turner, 2006). Consequently, individuals make a deliberate decision, assessing the likely outcomes of their behaviors.

The work motivation and flexible orientation to the role are other antecedents of the spirit of initiative. Thus, IT managers must identify individual differences and control contextual variables such as autonomy, managerial support, trust in colleagues, a sense of fairness at work, which can affect the cognitive-motivational state of public servants, influencing the perception of success of adopting ITG mechanisms and improving the maturity levels of these mechanisms.

\section{FINAL REMARKS}

This research demonstrates that there is a relationship between the organizational citizenship behavior and the maturity of ITG mechanisms, which has practical implications for IT professionals in government as well as theoretical contributions to the IT governance organizational field.

One of the main theoretical contributions is the validation of the OCB dimensions proposed in literature (Rego, Ribeiro, \& Cunha, 2010), showing that it can be used to evaluate the behavior of individuals related to the adoption of different management and governance mechanisms. Another contribution is the demonstration of the existence of a positive and significant relationship between the spirit of initiative and the maturity of the ITG mechanisms. It shows that effective ITG promotes autonomy and proactivity, which are essential to meet expectations related to administrative burden reduction, government openness, and citizen-centered government.
The influence of the spirit of initiative on ITG mechanisms maturity also demonstrates the complexity of the phenomenon studied, which is an intricate process of organizational change through behavioral changes in the role of IT. This research also contributes to its field because ITG in the context of public organizations is understudied (Nfuka \& Rusu, 2011), as well as the behavioral side of ITG (Teo et al., 2013).

As a practical contribution, this study demonstrates that ITG adoption processes should consider the impact of changes not only on processes and structures, but also on the behavior of individuals in organizations. Since IT is political and social (Bekkers \& Homburg, 2002) and ITG adoption changes the meaning of IT in organizations, the discussion moves from the IT sector to the use of IT throughout the organization and how IT resources might create public value.

IT in the public sector can increase trust and promote a participatory citizen-government relationship as well as a means for equitable policies (Schwarz, 2005), which is likely to be effective and long-term when it is part of a behavioral change supported by a governance process that maintains changes over time. This behavioral change is crucial to build an open government, which requires going beyond simplistic approaches such as the implementation of a participatory budgeting tool, even though tools are the way to easily reach society.

ITG principles contribute to enhancing innovation capabilities (Luna-Reyes et al., 2020), which is essential, especially in public organizations, when the contracting of different competencies might be not so easy. IT principles that are not changed at each mandate to simply oppose the previous administration are more consistent, and their continuity is more likely to be maintained over time when they are part of an ITG initiative. IT managers need to consider that individuals' behavioral changes, especially those that encourage the spirit of initiative, contribute to the definition of ITG policies that encourage meeting citizen demands and reaching government goals.

An alternative explanation for the non-confirmation of hypotheses $\mathrm{H} 1, \mathrm{H} 3$, and $\mathrm{H} 4$ is the understanding that the adoption of ITG mechanisms does not have an external impact on the perception about the organization or the interpersonal relations of civil servants. In this regard, civil servants may not understand the adoption of ITG mechanisms as something normative that indicates compliance or that leads to conscientiousness to protect organizations' resources. Civil servants might not see the adoption of ITG mechanisms as negatively influencing the image of the organization or the interpersonal harmony. Thus, the dimensions of identification with the organization 
and interpersonal harmony would not be perceived as affecting ITG mechanisms maturity.

Another important reflection is that even though these hypotheses did not present a sufficient significance level to confirm them, the OCB has an expected correlation among their constituent factors. Thus, in the context of public organizations where these dimensions were studied, there might not be a direct effect of these factors on the maturity level of IT governance mechanisms, but still, this effect can contribute to the increase of the spirit of initiative.

Two limitations are important for the interpretation of the research results. The first relates to the predictive capacity of the proposed relationship model, requiring a larger number of confirmatory studies to improve these relationships. The second refers to the study context, considering that the data collection was carried out with civil servants of a Brazilian state. The application of the results to

\section{REFERENCES}

Ahmed, I., \& Nawaz, M. M. (2015). Antecedents and outcomes of perceived organizational support: A literature survey approach. Journal of Management Development, 34(7), 867-880. https://doi.org/10.1108/JMD-09-2013-0115

Ajzen, I. (1991). The theory of planned behavior. Organizational Behavior and Human Decision Processes, 50, 179-211. https://doi.org/10.1016/0749-5978(91)90020-T

Ajzen, I., \& Fishbein, M. (1977). Attitude-behavior relations: A theoretical analysis and review of empirical research. Psychological Bulletin, 84(5), 888-918. https://doi.org/10.1037/0033-2909.84.5.888

Ali, A., Nor, R. N. H., Abdullah, R., \& Murad, M. A. A. (2016). Developing conceptual governance model for collaborative knowledge management system in public sector organisations. Journal of Information and Communication Technology, 15(2), 171-191. Retrieved from http://ejournal.uum.edu.my/index.php/jict/article/view/8213

Bandura, A. (1989). Human agency in social cognitive theory. American Psychologist, 44(9), 1175-1184. https://doi.org/10.1037/0003-066X.44.9.1175

Barnard, C. I. (1938). The functions of the executive. Cambridge, MA: Harvard University Press

Bekkers, V., \& Homburg, V. (2002). Administrative supervision and information relationships. Information Polity, 7(2-3), 129-141. Retrieved from https://content.iospress.com/ articles/information-polity/ip000007 other federal units or even in private sector organizations needs to consider geographic, cultural, and political issues.

Regarding follow-up and future studies, we suggest the validation of the proposed relationship model in other units of the federation or branches of the municipal and federal public administration, ensuring greater reliability and comprehensiveness. Finally, the moderating effect of individual characteristics (satisfaction, perception of justice, commitment, and trust in leaders), personality (conscientiousness, pleasantness, positive and negative affectivity), or individual competencies and differences (experience, formation, need for independence, and indifference to rewards) may influence the relationship between the OCB dimensions and the effectiveness of the ITG models. These characteristics may exert positive or negative effects on individuals' OCB (Organ, Podsakoff, \& Mackenzie, 2006), which constitute an aspect to be explored in future researches.

Bentler, P. M., \& Speckart, G. (1979). Models of attitudebehavior relations. Psychological Review, 86(5), 452-464. https://doi.org/10.1037/0033-295X.86.5.452

Bies, R. J. (1989). Organizational citizenship behavior: The good soldier syndrome. Academy of Management Review, 14(2), 150-312. https://doi.org/10.5465/AMR.1989.4282145

Bradley, R. V., \& Pratt, R. M. E. (2011). Exploring the relationships among corporate entrepreneurship, IT governance, and risk management. Proceedings of the Annual Hawaii International Conference on System Sciences, Kauai, HI, USA, 44. https://doi.org/10.1109/HICSS.2011.203

Chin, W.W. (1998). The partial least squares approach to structural equation modeling. In G. A. Marcoulides (Ed.), Modern methods for business research (pp. 295-336). Mahwah, NJ: Lawrence Erlbaum Associates.

Collares, M. L. (2020). Governança corporativa: Fator preponderante no ativismo de acionistas no Brasil. Revista de Administraçâo Contemporânea, 24(5), 414-431. https://doi.org/10.1590/1982-7849rac2020190338

Currie, W. (2008). Institutionalization of IT compliance: A longitudinal study. Proceedings of the International Conference on Information Systems, Paris, France, 29. Retrieved from https://aisel.aisnet.org/icis2008/182 
Cunha, M. P., Rego, A., \& Clegg, S. R. (2010). Obedience and evil: From milgram and kampuchea to normal organizations. Journal of Business Ethics, 97, 291-309. https://doi.org/10.1007/s10551-010-0510-5

Cruz, J. B. da, Júnior. (2004). Repensando as funçóes do executivo. In A. S. Laner \& J. P. da Cruz Júnior (Orgs.), Repensando as organizaçôes: Da formação à participação (pp. 363-387). Florianópolis: Fundação Boiteux.

Dada, D. (2006). The failure of e-government in developing countries: A literature review. The Electronic Journal of Information Systems in Developing Countries, 26(1), 1-10. https://doi.org/10.1002/j.1681-4835.2006.tb00176.x

DeHaes, S., \&Van Grembergen, W. (2009).An exploratorystudyinto IT governance implementations and its impact on business/ IT alignment. Information Systems Management, 26(2), 123-137. https://doi.org/10.1080/10580530902794786

Diniz, E. H., Barbosa, A. F., Junqueira, A. R. B., \& Prado, O. (2009). O governo eletrônico no Brasil: Perspectiva histórica a partir de um modelo estruturado de análise. Revista de Administração Pública, 43(1), 23-48. https://doi.org/10.1590/S0034-76122009000100003

Fernandes, C. M., Siqueira, M. M. M., \& Vieira, A. M. (2014). Impacto da percepçáo de suporte organizacional sobre o comprometimento organizacional afetivo: O papel moderador da liderança. Pensamento Contemporâneo em Administração, 8(4), 140-162. https://doi.org/10.12712/rpca.v8i4.396

Fornell, C., \& Larcker, D. F. (1981). Structural equation models with unobservable variables and measurement error: Algebra and statistics. Journal of Marketing Research, 18(3), 382-388. https://doi.org/10.2307/3150980

He, J. J., Ye, C. M., \& Xu, F. Y. (2010). A study on organizational change and human behavior in the process of organization information reform. 2010 International Conference on Management and Service Science, Wuhan, China. https://doi.org/10.1109/ICMSS.2010.5578116

Henseler, J., Ringle, C. M., \& Sinkovics, R. R. (2009). The use of partial least squares path modeling in international marketing. In R. R. Sinkovics, P. N. Ghauri (Eds.), New challenges to international marketing (pp. $277-$ 319). Bingley: Emerald Group Publishing Limited. https://doi.org/10.1108/S1474-7979(2009)0000020014

Joia, L. A., \& Magalhães, C. (2009). Evidências empíricas da resistência à implantação de prescrição eletrônica: Uma análise explano-exploratória. RAC-Eletrônica, 3(1), 81104. Retrieved from http://www.spell.org.br/documentos/ ver/31129/evidencias-empiricas-da-resistencia-a-implantac---

Katz, D., \& Kahn, R. L. (1978). The social psychology of organizations (Vol. 2, Cap. 2, pp. 14-29). New York: Wiley .

Lin, C., \& Wittmer, J. L. S. (2017, July). Proactive information security behavior and individual creativity: Effects of group culture and decentralized IT governance. 2017 IEEE International Conference on Intelligence and Security Informatics: Security and Big Data, Beijing, China. https://doi.org/10.1109/ISI.2017.8004865
Luna-Reyes, L., Juiz, C., Gutierrez-Martinez, I., \& Duhamel, F. B. (2020). Exploring the relationships between dynamic capabilities and IT governance: Implications for local governments. Transforming Government: People, Process and Policy, 14(2), 149-169. https://doi.org/10.1108/TG-09-2019-0092

Magnusson, J., \& Bygstad, B. (2013). Why I act differently: Studying patterns of legitimation among CIOs through motive talk. Information Technology and People, 26(3), 265-282. https://doi.org/10.1108/ITP-10-2012-0117

Mendonça, C. M. C., Guerra, L. C. B., Souza Neto, M. V., \& Araújo, A. G.. (2013). Governança de tecnologia da informação: Um estudo do processo decisório em organizaçóes públicas e privadas. Revista de Administração Pública, 47(2), 443-468. https://doi.org/10.1590/S0034-76122013000200008

Morisse, M., Horlach, B., Kappenberg, W., Petrikina, J., Robel, F., \& Steffens, F. (2014, March). Trust in network organizations: A literature review on emergent and evolving behavior in network organizations. Proceedings of the Hawail International Conference on System Sciences, Waikoloa, HI, USA, 47. https://doi.org/10.1109/HICSS.2014.561

Nfuka, E. N., \& Rusu, L. (2011). The effect of critical success factors on IT governance performance. Industrial Management \& Data Systems, 111(9), 1418-1448. https://doi.org/10.1108/02635571111182773

Organ, D. W. (2015). Organizational citizenship behavior. In J. D. Wright (Ed.), International Encyclopedia of the Social \& Behavioral Sciences (2 ed., pp. 317-321). https://doi.org/10.1016/B978-0-08-097086-8.22031-X

Organ, D. W., Podsakoff, P. M., \& MacKenzie, S. B. (2006). Organizational citizenship behavior: Its nature, antecedents, and consequences. Thousand Oaks, CA: Sage Publications. https://doi.org/10.4135/9781452231082

Parker, S. K., Williams, H. M., \& Turner, N. (2006). Modeling the antecedents of proactive behavior at work. Journal of Applied Psychology, 91(3), 636-652. https://doi.org/10.1037/0021-9010.91.3.636

Peters, B. G. (1998). Managing horizontal government: The politics of co-ordination. Public Administration, 76(2), 295-311. https://doi.org/10.1111/1467-9299.00102

Rego, A. (1999). Comportamentos de cidadania organizacional: Operacionalização de um constructo. Psicologia, 13(1-2), 127-148. https://doi.org/10.17575/rpsicol.v13i1/2.563

Rego, A. (2003). Comprometimento organizacional e ausência psicológica: Afinal, quantas dimensóes? Revista de Administração de Empresas, 43(4), 25-35. https://doi.org/10.1590/S0034-75902003000400003

Rego, A., \& Cunha, M. P. (2010). Organisational justice and citizenship behaviors: A study in the portuguese cultural context. Applied Psychology, 59(3), 404-430. https://doi.org/10.1111/j.1464-0597.2009.00405.x

Rego, A., Ribeiro, N., \& Cunha, M. P. (2010). Perceptions of organizational virtuousness and happiness as predictors of organizational citizenship behaviors. Journal of Business Ethics, 93(2), 215-235. https://doi.org/10.1007/s10551-009-0197-7 
Ringle, C. M., Silva, D., \& Bido, D. S. (2014). Modelagem de equaçóes estruturais com utilização do SmartPLS. Revista Brasileira de Marketing, 13(2), 54-71. https://doi.org/10.5585/remark.v13i2.2717

Rodrigues, J. G. L., \& Souza Neto, J. (2012). Diretrizes para implantaçáo da governança de tecnologia da informação no setor público brasileiro à luz da teoria institucional. Revista do Serviço Público, 63(4), 475-497. https://doi.org/10.21874/rsp.v63i4.108

Sambamurthy, V., \& Zmud, R. (1999). Arrangements for information technology governance: A theory of multiple contingencies. Management Information Systems Quarterly, 23(2), 261-290. https://doi.org/10.2307/249754

Sarstedt, M., Ringle, C. M., Smith, D., Reams, R., \& Hair, J. F., Jr. (2014). Partial least squares structural equation modeling (PLS-SEM): A useful tool for family business researchers. Journal of Family Business Strategy, 5(1), 105115. https://doi.org/10.1016/j.jfbs.2014.01.002

Schwarz, G. M. (2005). The social study of information and communication technology: Innovation, actors, and contexts. Administrative Science Quarterly, 50(1), 152155. https://doi.org/10.2189\%2Fasqu.2005.50.1.152

Scott, R. W. (1995). Institutions and organizations: Ideas, interests, and identities. Thousand Oaks, CA: Sage Publishing.

Siqueira, M. M. M. (2003). Proposição e análise de um modelo para comportamentos de cidadania organizacional. Revista de Administração Contemporânea, 7(spe), 165-184. https://doi.org/10.1590/S1415-65552003000500009

Smith, C. A., Organ, D. W., \& Near, J. P. (1983). Organizational citizenship behavior: Its nature and antecedents. Journal of Applied Psychology, 68(4), 653-663. https://doi.org/10.1037/0021-9010.68.4.653

Smits, D., \& Van Hillegersberg, J. (2015, March). IT governance maturity: Developing a maturity model using the delphi method. Proceedings of the Annual Hawaii International Conference on System Sciences. Kauai, HI, USA, 48. https://doi.org/10.1109/HICSS.2015.541

Smits, D., \& Van Hillegersberg, J. (2014). The development of an IT governance maturity model for hard and soft governance. Proceedings of the European Conference on Information Management and Evaluation, Ghent, Belgium, 8. Retrieved from https://research.utwente.nl/en/publications/ the-development-of-an-it-governance-maturity-model-forhard-and-s
Teo, W. L., Manaf, A. A., \& Choong, P. L. F. (2013). Application of the theory of planned behaviour in information technology governance. Proceedings of the International Business Information Management Association Conference, Vienna, Austria, 21.

Weill, P., \& Ross, J. W. (2004). IT governance: How top performers manage IT decision rights for superior results. Boston, MA: Harvard Business School Press.

Wiedenhöft, G. C., Luciano, E. M., \& Macadar, M. A. (2016). Information technology governance in public organizations: Understanding the expectations of its adoption through the lens of organizational citizenship. Proceedings of the European Conference on Information Systems, Instanbul, Turkey, 24.

Wiedenhöft, G. C., Luciano, E. M., \& Pereira, G. V. (2019). Information technology governance institutionalization and the behavior of individuals in the context of public organizations. Information Systems Frontiers. https://doi.org/10.1007/s10796-019-09945-7

Wiedenhöft, G. C, Luciano, E. M., \& Pereira, G. V. (2017, June). Institutionalization of information technology governance and the behaviour of individuals in the public organizations context.ProceedingsoftheEuropean ConferenceonInformation Systems, Guimarães, Portugal, 25. Retrieved from https://api.semanticscholar.org/CorpusID:13558899

Wiedenhöft, G. C., Luciano, E. M., \& Magnagnagno, O. A. (2017). Information technology governance in public organizations: Identifying mechanisms that meet its goals while respecting principles. Journal of Information Systems and Technology Management, 14(1), 69-87. Retrieved from http://www.jistem.tecsi.org/index.php/jistem/article/vi ew/10.4301\%25S1807-17752017000100005

Wiedenhöft, G. C., Luciano, E. M., \& Porto, J. B. (2019). Impacts of the spirit of initiative and identification with the organization on IT governance effectiveness perception in public organizations. Revista de Gestão, 26(1), 5-21. https://doi.org/10.1108/rege-01-2018-0014

Zerpa, C. (2009). Improving governance with an e-government maturitymodel.Proceedingsofthe3rdInternationalConference on Theory and Practice of Electronic Governance, New York, USA. https://doi.org/10.1145/1693042.1693115 


\section{Authorship}

\section{Guilherme Costa Wiedenhöft*}

Universidade Federal do Rio Grande, Instituto de Ciências Econômicas, Administrativas e Contábeis

Av. Itália, s/n, Km 8, Carreiros, Rio Grande, RS, Brazil.

E-mail address: wiedenhoft@furg.br

(1) https://orcid.org/0000-0003-2426-4396

\section{Edimara Mezzomo Luciano}

Pontifícia Universidade Católica do Rio Grande do Sul, Business School

Av. Ipiranga, no 6681, Prédio 50, Partenon, 90619-900, Porto Alegre, RS, Brazil.

E-mail address: eluciano@pucrs.br

(1) https://orcid.org/0000-0002-2847-8845

* Corresponding Author

\section{Funding}

The authors thank the European Commission within the ERASMUS+ Programme, in the context of the project CAP4CITY 598273-EPP-1-2018-1-AT-EPPKA2-CBHE-JP for the financial support.

\section{Copyrights}

RAC owns the copyright to this content.

\section{Conflict of Interests}

The authors have stated that there is no conflict of interest.

\section{Plagiarism Check}

The RAC maintains the practice of submitting all documents approved for publication to the plagiarism check, using specific tools, e.g.: iThenticate.

\section{Peer Review Method}

This content was evaluated using the double-blind peer review process. The disclosure of the reviewers' information on the first page is made only after concluding the evaluation process, and with the voluntary consent of the respective reviewers.

\section{Authors' Contributions}

$1^{\text {st }}$ author: conceptualization (equal); data curation (equal); formal analysis (lead); funding acquisition (supporting); investigation (equal); methodology (lead); project administration (equal); resources (equal); software (lead); supervision (supporting); validation (equal); visualization (equal); writing-original draft (lead); writing-review \& editing (lead).

$2^{\text {nd }}$ author: conceptualization (equal); data curation (equal); formal analysis (equal); funding acquisition (lead); investigation (equal); methodology (equal); project administration (equal); resources (equal); software (equal); supervision (lead); validation (lead); visualization (equal); writing-original draft (equal); writing-review \& editing (equal).

\section{Data Availability and Reuse}

The authors acknowledge that the data has been used in the following studies: "Impacts of the spirit of initiative and identification with the organization on IT governance effectiveness perception in public organizations" published at Revista de Gestão in 2019 and it is available on: https://doi. org/10.1108/REGE-01-2018-0014; "Information Technology Governance Institutionalization and the Behavior of Individuals in the Context of Public Organizations" published at Information Systems Frontiers in 2020 and it is available on: https://doi.org/10.1007/s10796-019-09945-7

The datasets generated and/or analyzed during the current study are available in the Harvard Dataverse repository and can be accessed at:

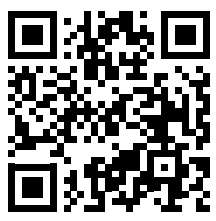

Guilherme Wiedenhöft; Edimara Mezzomo Luciano, 2020, "Replication Data for: Going the extra mile: Impact of Individuals' Behavior on Information Technology Governance", Harvard Dataverse, V1.

https://doi.org/10.7910/DVN/JWMEZT

RAC encourages data sharing but, in compliance with ethical principles, it does not demand the disclosure of any means of identifying research subjects, preserving the privacy of research subjects. The practice of open data is to enable the reproducibility of results, and to ensure the unrestricted transparency of the results of the published research, without requiring the identity of research subjects. 